\title{
Framing Media Online Detik.com Terhadap Pemberitaan Korban Pengeroyokan oleh Bobotoh
}

\author{
Muhammad Refi Sandi, Maimon Herawati, dan Justito Adiprasetio \\ Fakultas Ilmu Komunikasi, Universitas Padjadjaran \\ sandirefi21@gmail.com
}

\begin{abstract}
This study aims to determine the news framing of victims that were beaten by bobotoh on the online news site Detik.com. The object of this study is a series of news on Detik. com that exposed that name of the victims. The research method used was qualitative research with framing analysis of Zhongdan Pan and Gerald M. Kosicki model, by judging from the syntactic structure, scripts, thematic, and rhetorical to determine how the media construct news discourse, by emphasizing specific aspects. The results showed that of the 6 news that were studied, 4 of them featured the name of victims and 2 news articles contained the same contents, only a change of title. Detik.com frames the figure of HS victims in a syntactic structure, and Detik.com pays attention to the Cyber Media Coverage Guidelines. In the script structure, Detik.com features elements such as the location of the incident, the location of the crime scene, and the location of the interview. In the thematic structure, the theme of crime news is interesting because it has its own news value and news judgment for readers. Finally, the rhetorical structure shows Detik. com committing a body shaming violation of HS victims. Researchers concluded that Detik.com digged too deep regarding the personal life of HS, thus violating privacy. The researcher suggests that Detik.com understand the Cyber Media Coverage Guidelines and adhere to it in journalistic practices, and Detik.com reporters can pay attention to the Information and Electronic Transactions Law (ITE) especially article 27 paragraph 3 in journalistic practices.
\end{abstract}

Keywords: news; framing; beatings; code of ethic; guidelines

\begin{abstract}
Abstrak
Penelitian ini bertujuan mengetahui pembingkaian korban pengeroyokan oleh bobotoh pada situs berita online Detik.com. Objek penelitian ini adalah rangkaian berita dalam situs Detik.com yang mengekspos nama korban. Metode penelitian yang digunakan yaitu penelitian kualitatif dengan analisis framing model Zhongdan Pan dan Gerald M. Kosicki, yang dilihat dari struktur sintaksis, skrip, tematik, dan retoris untuk mengetahui cara media mengonstruksi sebuah wacana berita, dengan melakukan penonjolan tertentu. Hasil penelitian menunjukkan bahwa dari 6 berita yang diteliti, 4 berita menonjolkan nama korban serta 2 berita yang mengandung isi yang sama hanya perubahan judul. Detik.com membingkai sosok korban HS dalam struktur sintaksis, Detik.com memperhatikan Pedoman Pemberitaan Media Siber. Pada stuktur skrip, Detik.com menonjolkan unsur di mana seperti lokasi peristiwa, lokasi tempat kejadian perkara, dan lokasi wawancara. Dalam struktur tematik, Detik.com tema berita kejahatan menarik karena memiliki news value dan news judgment tersendiri bagi para pembaca. Terakhir, struktur retoris menunjukkan Detik.com melakukan pelanggaran body shaming terhadap korban HS. Peneliti menyimpulkan bahwa Detik.com menggambarkan HS terlalu dalam hingga kehidupan pribadinya, sehingga hal tersebut melanggar privasi korban. Peneliti menyarankan agar Detik.com memahami Pedoman Pemberitaan Media Siber dan mematuhinya dalam praktik jurnalistik. Serta wartawan Detik.com dapat memperhatikan Undang-Undang Informasi dan Transaksi Elektronik (ITE) khususnya pasal 27 ayat 3 dalam praktik jurnalistik.
\end{abstract}

Kata kunci: berita; pembingkaian; pengeroyokan; kode etik; pedoman

Korespondensi: Muhammad Refi Sandi, S.I.Kom, Fakultas Ilmu Komunikasi Universitas Padjadjaran, J1. Raya Bandung Sumedang KM.21, Kec. Jatinangor, Kabupaten Sumedang, Jawa Barat, 45363,

Email: sandirefi21@gmail.com

Menyerahkan: Juli 2020, Diterima: Agustus 2021, Terbit: Januari 2022

ISSN: 2549-0559 (cetak), ISSN: 2549-1946 (online), Website: http://jurnal.unpad.ac.id/kajian-jurnalisme 
146 | Kajian Jurnalisme

Volume 05 Nomor 02 Tahun 2022

DOI: $10.24198 / j \mathrm{kj} . v 5 \mathrm{i} 2.28886$

\section{PENDAHULUAN}

Pertandingan classic sepak bola di Indonesia antara Persib Bandung vs Persija Jakarta tersaji Minggu, (23/9/2018) di Stadion Gelora Bandung Lautan Api (GBLA), Bandung. Kemenangan Persib Bandung ternodai karena terjadinya pengeroyokan oknum bobotoh terhadap HS yang merupakan anggota kelompok suporter Persija Jakarta atau 'the jak'. Kejadian tersebut bermula dari postingan HS di sosial media Instagram yang memposting kata 'awayday' dengan latar foto kartu tanda anggota 'the jak' yang menandakan korban HS berangkat ke Bandung untuk menyaksikan pertandingan tersebut. Hal tersebut membuat 'bobotoh' geram dan langsung melakukan sweeping di sekitar Stadion GBLA. Tepat pukul 13.00 WIB atau sebelum pertandingan berlangsung terjadi sebuah aksi pengeroyokan oleh oknum 'bobotoh' terhadap HS suporter 'the jak' hingga meninggal. Hal tersebut membuat peneliti tertarik untuk melihat bagaimana media massa mengonstruksi suatu peristiwa, khususnya pemberitaan kasus pengeroyokan oleh 'bobotoh' (Sandi, 2020). Pasca peristiwa tersebut, media-media di Indonesia secara eksesif memberitakan hal yang juga teresonansi dengan sebaran informasi di media sosial, hal yang membuat pemberitaan memiliki nuansa personal dan emosional. Korban pengeroyokan diekspos namanya, dan ditonjolkan aspek personalnya. Detik.com sebagai salah satu media online terdepan di Indonesia dan menjadi referensi bagi dunia media di Indonesia dalam hal kecepatan dan gaya bahasa, turut serta melakukan hal yang sama (Adiprasetio, 2019a; Margianto \& Syaefullah, 2013). Beberapa studi sebelumnya menunjukkan bagaimana pada peristiwa yang sensasional, media turut serta melakukan trivialisasi yang potensial membuat efek pemberitaan terhadap publik menjadi sangat besar (Adiprasetio, 2019b; Adiprasetio \& Wibowo, 2019). Penelitian ini bertujuan untuk memeriksa secara lebih dalam bagaimana Detik. com membingkai pemberitaan atas korban pengeroyokan oleh bobotoh.

Kericuhan hingga berujung bentrok antar suporter klub sepakbola di Indonesia bukan hal yang asing lagi. Faktor pemicu kericuhan hingga berujung bentrok dapat dipicu dari sebuah rivalitas atau "musuh abadi" (Hapsari \& Wibowo, 2015). Rivalitas itu dapat terlihat antara 'bonek' suporter klub Persebaya Surabaya dengan 'aremania' suporter klub Arema FC, 'bobotoh' atau yang lebih dikenal dengan 'viking' suporter klub kebanggaan Jawa Barat Persib Bandung dengan 'the jakmania' suporter klub kebanggaan Ibu Kota Persija Jakarta (Sandi, 2020). Rivalitas 'bobotoh' atau 'viking' dengan 'the jakmania', salah satu rivalitas suporter yang paling disoroti di Indonesia. Rivalitas keduanya tak jarang berujung dengan hilangnya nyawa salah satu suporter. Sejak 2012 hingga saat ini, terhitung sudah ada 7 korban jiwa akibat rivalitas kedua suporter klub tersebut. Terakhir pada 23 September 2018, seorang suporter 'jakmania' HS dipukuli hingga tewas oleh oknum 'bobotoh' di stadion Gelora Bandung Lautan Api, Bandung (Nugroho, 2018).

Fans ialah pemain kedua belas di lapangan setelah kesebelas pemain yang bertanding. Dalam olahraga sepakbola, suporter dianggap sebagai pemain kedua belas setelah sebelas pemain utama yang bertanding di lapangan, suporter sepakbola dianggap dapat membangkitkan suasana dalam sebuah pertandingan dengan tujuan meningkatkan daya juang dan semangat sebuah klub yang didukung bahkan dapat menjatuhkan mental klub lawan (Ridwayanti, 2008). Sebuah klub sepak bola mengelola para suporter dengan maksud meningkatkan citra suatu klub. Bagi para suporter, kemenangan dalam sebuah pertandingan dapat memberikan rasa bangga dalam dirinya. Namun, perasaan bahagia dan euforia suporter yang klubnya meraih kemenangan memancing amarah suporter klub yang kalah. Perasaan tersebut yang sulit terkontrol dapat memicu terjadinya bentrok antar suporter (Hapsari \& Wibowo, 2015). Suporter sebuah klub sebagai pemain kedua belas akan melakukan segala cara demi sebuah kemenangan tim kebanggaannya, termasuk melakukan aksi intimidasi kepada suporter maupun klub lawan 
bahkan hingga aksi kekerasan berujung perusakan fasilitas umum (Sukarmin, 2010).

Fanatisme suporter yang berlebihan akan menjadi awal mula rivalitas berujung bentrokan antar suporter. Salah satu contoh fanatisme suporter terhadap klub yang berujung hilangnya nyawa suporter ialah meninggalnya suporter 'the jak' di Bandung. Hal ini menarik perhatian media di Indonesia sebab video amatir yang merekam peristiwa pengeroyokan tersebut tersebar luas di media sosial. Peningkatan ketersebaran informasi di media sosial direspon oleh media online, dengan ikut serta menerbitkan informasi-informasi terkait peristiwa tersebut. Berikut media di Jakarta dan Bandung yang memberitakan kejadian tewasnya suporter 'the jak' tersebut pada tabel 1 .

Tabel 1. Perbandingan Jumlah Berita Terkait Pengeroyokan oleh 'Bobotoh' edisi 23 - 28 September 2018

\begin{tabular}{|c|c|}
\hline Nama Media & Jumlah Berita \\
\hline Tribunjabar.id & 154 \\
\hline Detik.com & 72 \\
\hline Kompas.com & 66 \\
\hline CNNIndonesia.com & 40 \\
\hline Galamedianews.com & 18 \\
\hline IDNTimes.com & 6 \\
\hline
\end{tabular}

Sumber: diolah dari: Sandi (2020)

Peneliti memilih topik pemberitaan ini karena permasalahan bentrok antar suporter terjadi berulang sepanjang sejarah persepakbolaan di Indonesia. Kejadian meninggalnya suporter 'the jak' terjadi pada 2018 silam di Kota Bandung. Peneliti menganggap kasus pemberitaan ini relevan untuk diteliti karena media memiliki kemampuan melakukan pembingkaian fakta dari sebuah peristiwa. Pembingkaian media terhadap kasus pengeroyokan yang berujung hilangnya nyawa salah satu suporter memungkinkan terjadinya dendam atau reproduksi kekerasan antar kedua suporter atau dapat meredakan ketegangan antar kedua suporter tersebut.

Mass media atau yang lebih dikenal media massa memiliki peran penting bagi penyalur informasi khalayak (audience). Media massa sebagai platform atau sarana penunjang kebutuhan infomasi (inform) serta hiburan (entertaint) bagi khalayak (audience) (Cangara, 2003). Media massa sebagai platform penyampaian informasi atau pesan dari komunikator ke komunikan atau sumber berita kepada khalayak (audience) melalui berbagai platform seperti surat kabar, tabloid, radio, televisi, film, dan internet. Adapun fungsi media massa, yaitu to inform (memberi informasi), to educate (mendidik), to persuade (membentuk opini), serta to entertaint (menghibur) khalayak (Effendy, 2004).

Dengan hadirnya media massa, khalayak dapat memenuhi kebutuhan atas segala hal khususnya kebutuhan informasi. Media online atau dalam jaringan tergolong new media. Meskipun tidak menghilangkan unsur media tradisional atau media terdahulu seperti cetak, radio, maupun televisi, melainkan hadirnya media dalam jaringan menggabungkan media baru dengan media tradisional. Adanya perpaduan antara teks, audio, dan video yang dipadukan dengan sebuah teknologi internet memungkinkan tidak adanya batas dalam memproses dan menyebarkan berita melalui media dalam jaringan ini. Media ini pun dapat berkomunikasi dua arah dengan khalayak melalui kolom komentar yang tersedia (Santana, 2005:135-128).

Memasuki zaman digitalisasi kini, pemberitaan melalui media massa dalam jaringan atau jurnalisme online terus melakukan perkembangan. Adapun ciri khas dari media massa dalam jaringan ialah dapat memberitakan suatu peristiwa di publikasi dengan cepat sehingga 
148 | Kajian Jurnalisme

Volume 05 Nomor 02 Tahun 2022

DOI: $10.24198 / \mathrm{jkj} . v 5 \mathrm{i} 2.28886$

memudahkan khalayak untuk segera mengakses informasi secara up to date, adapun kelebihan media massa dalam jaringan dapat diperbarui dan dihapus kapan saja. Jurnalisme online sangat mempertimbangkan multiplatform atau gabungan antara teks, gambar, audio, dan video. Sehingga memungkinkan adanya interaksi dua arah antara media massa dengan khalayak melalui kolom komentar yang tersedia (Romli, 2014: 98-99). Media dalam jaringan memiliki keunggulan, yaitu pertama, informasi bersifat kebaruan atau up to date, kedua, bersifat waktu sebenarnya atau real time, ketiga, dapat diakses di mana dan kapan saja (Suprobo, Siahainenia, \& Sari, 2016: 119-138).

Pandangan konstruksi media tidaklah sebuah platform yang bebas, melainkan ia menjadi subjek yang mengonstruksi sebuah realitas yang ada, lengkap dengan pandangan yang bias di mata khalayak dan pemihakannya terhadap suatu hal (Eriyanto, 2011). Media dapat dikatakan sebagai sarana konstruksi sosial yang mendefinisikan realitas yang berkembang di khalayak. Setiap media massa memiliki kepentingan di antaranya politik, ekonomi dan ideologi. Maka ada catatan penting mengenai peranan media yang masih banyak terperangkap dalam konteks bisnis semata. Pada "The Political Economy of Communication", Vincent Mosco (1996), memaparkan definisi tentang komodifikasi, yaitu mengenai pemanfaatan isi media dilihat dari kegunaannya sebagai barang yang dipasarkan. Lebih jelas Mosco memaparkan bahwa bentuk komoditas di dalam komunikasi terbagi dua, yaitu komodifikasi konten media dan komodifikasi khalayak atau audience. Inti pesan atau karya jurnalisme suatu media merupakan bentuk komodifikasi yang utama. Kumpulan data dan informasi yang pada awalnya tidak bermakna kemudian diolah menjadi hal yang bermakna sebagai "nilai tukar" (Mosco, 1996). Dalam kata lain, ada media yang melakukan transaksi konten media tersebut langsung dengan khalayak atau audience, ada media yang "menjual" terlebih dahulu kepada pengiklan baru sampai ke khalayak atau audience (Mosco, 1996).

Framing ialah sebuah penyajian pada suatu pendekatan konstruktivis dengan tujuan mengoreksi sudut pandang berita pada fokus utama yaitu konseptualisasi konten berita ke dalam operasionalisasi secara empiris dengan struktur sintaksis, skrip, tematik, dan retoris (Pan \& Kosicki, 1993: 55-75). Pada tulisannya Pan dan Kosicki (1993) mempertegas bahwa keempat unsur struktur tersebut berpadu dalam proses pembentukan tema atau ide sebuah narasi pemberitaan dalam suatu koherensi global (Pan \& Kosicki, 1993: 56). Model ini beranggapan bahwa suatu pemberitaan mempunyai bingkai yang menjadi pusat ide (Sobur, 2006: 162). Dalam sebuah pembingkaian terdapat perpaduan unsur antara sumber berita, latar informasi, penggunaan kalimat dalam sebuah teks secara menyeluruh (Pan \& Kosicki, 1993: 57). Suatu pembingkaian memiliki hubungan dengan sebuah makna. Hal tersebut terlihat dari persepsi seseorang terhadap suatu peristiwa (Sobur, 2006: 162).

Terdapat dua pendekatan untuk memeriksa framing pemberitaan, yaitu dengan pendekatan kuantitatif (Adiprasetio, 2020; Adiprasetio \& Larasati, 2020), atau pendekatan kualitatif (D'Angelo \& Kuypers, 2016). Pendekatan kualitatif digunakan dalam penelitian ini terutama mempertimbangkan pada bisa didapatkannya elaborasi yang mendalam atas analisis yang dilakukan. Mengingat pendekatan kuantitatif walaupun menawarkan pendekatan yang lebih sistematik dengan potensinya untuk dapat memeriksa data yang besar, seringkali tidak bisa sampai menjawab pertanyaan yang lebih jauh ketimbang sekadar menguraikan secara deskriptif bangunan bingkai dari media atas peristiwa (D'Angelo \& Kuypers, 2016).

Entman (1993) menjelaskan terdapat faktor penting dalam proses pembingkaian yaitu seleksi dan penekanan. Framing merupakan proses seleksi sebuah realitas yang berkembang, dengan tujuan membentuk sebuah realitas terlihat lebih menonjol atau mendominasi dalam konten teks berita (Scheufele, 1999). Pembingkaian ialah suatu pendekatan dengan tujuan 
mengetahui bagaimana pandangan atau perspektif wartawan dalam memilah isu serta menulis menjadi berita. Sebuah pandangan wartawan akan menentukan fakta apa yang akan muncul berikutnya, bagian mana yang diambil, serta bagian mana yang dihilangkan, serta menjadi penentu arah berita tersebut. Oleh karena itu, berita dapat bersifat manipulatif dan bertujuan menguasai suatu subjek sebagai suatu yang legitimate, objektif, wajar, alamiah, atau tak terelakan (Sobur, 2006: 163).

Peneliti juga menggunakan teori hierarki pengaruh dengan tujuan untuk mengetahui pengaruh apa yang menjadi landasan pemberitaan korban pengeroyokan oleh 'bobotoh'. Teori ini menjelaskan penyebab pembentukan konten berita di media massa saat ini. Shoemaker dan Reese (1996) mencoba mengelaborasi alasan mengapa media massa memiliki perbedaan dan persamaan dalam proses liputan maupun isi konten beritanya (Adiprasetio, 2015). Dalam artian, teori hierarki pengaruh menjelaskan proses pembentukan berita tidak hanya tepengaruh dari wartawan maupun internal media, melainkan faktor eksternal pun dapat memengaruhi konten media massa. Shoemaker dan Reese dalam bukunya membagi ke dalam beberapa level pengaruh isi media yang memiliki pengaruh terhadap kebijakan redaksi dalam proses produksi konten berita, yaitu level individu, rutinitas media, level organisasi, level ektramedia, dan level ideologi (Shoemaker \& Reese, 1996: 313).

Di Indonesia, portal media online kian menjamur seiring dengan perkembangan teknologi, contoh dengan hadirnya Detik.com yang merupakan salah satu portal berita di Indonesia. Detik.com di bawah Detik Network (PT Trans Digital Media) yang bernaung di bawah CT Corp. Adapun produk digital yang merupakan bagian dari Detik Network adalah detik.com, pasangmata, adsmart, cnnindonesia, cnbcindonesia, insert! Live, detikshop, Trans Media Sosial. Detik.com memiliki ciri khas komunikasi dua arah dengan khalayak pembaca selain dengan kolom komentar melainkan bisa juga melalui impresi atau mood rating yang disediakan berbentuk emoticon (Detik.com, 2019).

Kemampuan jajaran redaksi dan wartawan dalam membingkai suatu peristiwa menjadi bagian yang diteliti dalam penelitian ini. Media daring dapat memberitakan puluhan hingga ratusan tulisan dari sebuah peristiwa. Kewajiban melaporkan berita dengan cepat sesuai deadline atau sesegera mungkin membuat keakuratan data dari suatu berita menjadi lemah, dalam penelitian Pew Research Center (2004) dengan hadirnya internet telah terjadi peningkatan jumlah arus informasi yang salah.

Berdasarkan pemilihan isu dan penempatan berita, peneliti berasumsi bahwa Detik.com melihat peristiwa tewasnya HS, seorang suporter 'the jakmania', di Bandung tersebut sebagai kasus kemanusian dan penting sebab kedua suporter memiliki jumlah anggota yang cukup banyak sehingga diberitakan secara konsisten selama tujuh hari mulai kejadian hingga putusan terhadap para tersangka. Maka, peneliti mencoba membedah konstruksi pemberitaan tentang tewasnya HS seorang suporter 'the jakmania' di Bandung dengan menggunakan metode analisis framing model Zongdan Pan dan Kosicki (1993).

Adapun tujuannya guna mengetahui secara detail mengenai pembingkaian peristiwa tewasnya HS seorang suporter 'the jakmania' di Bandung, peneliti ingin melihat pemilihan kata, gambar, serta kelengkapan $5 \mathrm{~W}+1 \mathrm{H}$ yang digunakan wartawan terhadap pemberitaan ini. Peneliti menggunakan metode kualitatif deskriptif dengan pendekatan framing analysis model Zhongdan Pan dan Gerald M. Kosicki (1993). Tujuan berikutnya ialah mengetahui proses wartawan dalam mengonstruksi sebuah realitas yang berkembang di masyarakat sehingga dapat menghasilkan sebuah berita untuk khalayak yang dapat dilihat dari beberapa struktur kalimat serta retorika yang ditonjolkan dari sebuah pemberitaan tersebut. Model Pan dan Kosicki (1993) ini memiliki empat struktur yaitu sintakis, skrip, tematik, dan retoris. Model 
150 | Kajian Jurnalisme

Volume 05 Nomor 02 Tahun 2022

DOI: $10.24198 / j \mathrm{kj} . v 5 \mathrm{i} 2.28886$

ini dirasa tepat untuk mengkaji cara wartawan atau editor detik.com merekonstruksi peristiwa yang diperoleh dari sumber teks berita seperti kata-kata dan simbol.

\section{METODE}

Penelitian ini merupakan penelitian kualitatif dengan pendekatan paradigma konstruktivis. Penelitian ini akan melihat bagaimana konstruksi yang dilakukan oleh Detik.com dalam membingkai pemberitaan korban pengeroyokan oleh bobotoh. Unit amatan dalam penelitian ini adalah Detik.com. Unit analisis dalam penelitian ini adalah berita yang dibuat oleh Detik. com terkait pemberitaan korban pengeroyokan oleh bobotoh. Data primer dalam penelitian ini diperoleh dari pemberitan Detik.com. Data sekunder merupakan data pendukung yang diperoleh dari sumber buku, internet, artikel, jurnal dsb. Pada penelitian ini, pengambilan data diperoleh dengan mengunduh berita mengenai korban (HS) yang dimuat dalam portal berita Detik.com selama periode 23-28 September 2018. Dalam penelitian ini, data disajikan dalam bentuk tabel hasil analisis dengan menggunakan model analisis Zhongdan Pan dan Gerald M. Kosicki (Pan \& Kosicki, 1993).

\section{Framing model Zhongdan Pan dan Gerald M. Kosicki}

Framing ialah sebuah penyajian pada suatu pendekatan konstruktivis dengan tujuan mengoreksi sudut pandang berita pada fokus utama yaitu konseptualisasi konten berita ke dalam operasionalisasi secara empiris dengan struktur sintaksis, skrip, tematik, dan retoris (Pan \& Kosicki, 1993: 55). Pada tulisannya Pan dan Kosicki (1993) mempertegas bahwa keempat unsur struktur tersebut berpadu dalam proses pembentukan tema atau ide sebuah narasi pemberitaan dalam suatu koherensi global (Pan \& Kosicki, 1993: 56). Dalam sebuah pembingkaian terdapat perpaduan unsur antara sumber berita, latar informasi, penggunaan kalimat dalam sebuah teks secara menyeluruh (Pan \& Kosicki, 1993: 56).

Model analisis framing Zhongdan Pan terbagi menjadi empat perangkat framing yaitu sintaksis, skrip, tematik dan retoris. Sintaksis, merupakan pola untuk mengatur kata atau frasa menjadi sebuah kalimat. Sebagian berita dicirikan dengan piramida terbalik. Biasanya mengacu kepada susunan lead, headline, kutipan, sumber, pernyataan dan penutup. Hal ini berkaitan dengan cara kerja wartawan dalam merangkai sebuah kejadian, opini, kutipan, serta pengamatan wartawan ke dalam susunan berita yang padu. Hubungan cara kerja wartawan dalam menceritakan sebuah peristiwa ke dalam berita disebut skrip. Sebuah skrip berita memiliki aturan tata bahasa yaitu $5 \mathrm{~W}+1 \mathrm{H}$ (what, where, when, why, who, and how). Sebuah skrip juga mengandung informasi lengkap dari sebuah peristiwa mulai awal, klimaks, dan akhir.

Tematik, memiliki hubungan dengan wartawan menceritakan isi pandangannya atas suatu peristiwa ke dalam hubungan antar kalimat yang membentuk teks yang padu secara keseluruhan. Retoris, memiliki hubungan dengan wartawan dalam menekankan makna tertentu ke dalam isi berita. Adapun cara yang dilakukan untuk menekankan makna atau memperkuat fakta digunakanlah pilihan kata, idiom, grafis dan gambar. Untuk menekankan isi berita kepada khalayak (Pan \& Kosicki, 1993: 60-62). Untuk memperjelas uraian di atas dapat melihat tabel 2. 
Volume 05 Nomor 02 Tahun 2022

DOI: $10.24198 /$ jkj.v5i2.28886

Tabel 2. Kerangka Framing Zhongdan Pan dan Gerald M. Kosicki

\begin{tabular}{|l|l|l|}
\hline \multicolumn{1}{|c|}{ Struktur } & \multicolumn{1}{|c|}{ Perangkat Framing } & \multicolumn{1}{c|}{ Unit yang diamati } \\
\hline $\begin{array}{l}\text { Sintaksis } \\
\text { Cara wartawan menyusun fakta }\end{array}$ & 1. Skema Berita & $\begin{array}{l}\text { Headline, lead, latar informasi, } \\
\text { kutipan, narasumber, pernyataan, } \\
\text { penutup }\end{array}$ \\
\hline $\begin{array}{l}\text { Skrip } \\
\text { Cara wartawan mengisahkan } \\
\text { fakta }\end{array}$ & $\begin{array}{l}\text { 2. Kelengkapan Berita } \\
\text { Tematik }\end{array}$ & $5 \mathrm{~W}+1 \mathrm{H}$ \\
Cara wartawan menulis fakta & $\begin{array}{l}\text { 3. Detail } \\
\text { 4. Koherasi } \\
\text { 6. Kata Ganti }\end{array}$ & $\begin{array}{l}\text { Paragraf, preposisi, kalimat, hubun- } \\
\text { gan antar kalimat }\end{array}$ \\
\hline $\begin{array}{l}\text { Retoris } \\
\text { Cara wartawan menekankan } \\
\text { fakta }\end{array}$ & $\begin{array}{l}\text { 7. Leksikon } \\
\text { 8. Grafis } \\
\text { 9. Metafora }\end{array}$ & Kata, idio, gambar/foto, dan grafis \\
\hline
\end{tabular}

Sumber: Pan \& Kosicki (1993: 66)

Peneliti menggunakan model analisis framing Zhongdan Pan dan Gerald M. Kosicki, pemaknaan redaksi Detik.com mengenai pemberitaan korban pengeroyokan oleh bobotoh dapat diobservasi secara menyeluruh, penggunaan tanda baca, kelengkapan unsur berita $(5 \mathrm{~W}+1 \mathrm{H})$ hingga cara wartawan mengisahkan dan menekankan fakta yang mereka miliki.

Keempat struktur d iatas merupakan satu kesatuan yang dapat membuktikan framing Detik.com dalam pemberitaan korban pengeroyokan oleh 'bobotoh'. Dengan hal lain, dapat diamati juga cara wartawan merangkai suatu kejadian, penggunaan kalimat, serta pemilihan kata. Ketika menulis sebuah berita dan menekankan makna atas kejadian, wartawan akan menggunakan segala strategi wacana untuk meyakinkan khalayak bahwa berita yang ditulis ialah benar sesuai fakta (Pan \& Kosicki, 1993: 55-75).

\section{Teori Hierarki Pengaruh}

Teori ini ialah yang memaparkan penyebab pengaruh isi konten berita media massa saat ini. Shoemaker dan Reese pada bukunya yang berjudul Mediating he Message: Theories Influences on Mass Media Content (1996) memiliki rasa penasaran terhadap media massa karena adanya perbedaan dan persamaan dalam proses liputan maupun isi konten beritanya. Dalam artian, teori hierarki pengaruh ini menjelaskan proses terbentuknya berita tidak hanya tepengaruh dari wartawan maupun internal media, melainkan faktor eksternal pun dapat memengaruhi konten media massa. Shoemaker dan Reese membagi ke dalam beberapa level pengaruh isi media yang memiliki pengaruh terhadap kebijakan redaksi dalam proses produksi konten berita, yaitu:

Level individu, level ini memiliki hubungan dengan latar profesional media. Faktor ini terlihat dari personal pengelola media dalam memengaruhi pemberitaan yang akan disajikan kepada khalayak. Suatu pemberitaan tidak terlepas dari faktor individu (wartawan) media tersebut, khususnya mengenai arah pemberitaan serta unsur-unsur yang mereka beritakan. Faktor pendorong terbentuknya level individu dari latar belakang dan karakteristik wartawan. Misalnya umur, agama, jenis kelamin, pendidikan, atau arah pada partai politik tertentu.

Rutinitas media, level ini memiliki hubungan dengan mekanisme terhadap penentuan sudut pandang berita. Masing-masing media memiliki kriteria atau prosedur standar terhadap berita yang akan disebarkan kepada khalayak. Dalam artian sebuah rutinitas media berkaitan dengan kebiasaan suatu media dalam pengemasan konten berita.

Level organisasi, level ini memiliki hubungan dengan latar belakang organisasi media 
152 | Kajian Jurnalisme

Volume 05 Nomor 02 Tahun 2022

DOI: $10.24198 / \mathrm{jkj} . v 5 \mathrm{i} 2.28886$

karena secara hipotesis dapat memengaruhi sebuah pemberitaan. Seluruh komponen dalam organisasi media dari mulai redaksi, pemasaran serta sirkulasi memiliki kepentingan masingmasing yang membuat tidak selalu sejalan. Maka dari itu, akan terjadi proses dialektika diantara mereka untuk mempertahankan kepentingan masing-masing. Faktor tersebut akan berpengaruh terhadap cara wartawan bersikap serta bagaimana suatu peristiwa tersaji dalam konten berita. Pada level organisasi ini pengaruh pemilik media melalui editor pada sebuah media memiliki pengaruh besar dibanding level lainnya karena kebijakan terbesar dipegang oleh pemilik media.

Level ekstramedia, level ini berhubungan dengan eksternal media seperti dari mana sumber berita, siapa pengiklan dan penonton, serta kontrol dari pemerintah dan lain sebagainya.

Level ideologi, level ini berhubungan dengan latar belakang profesional pengelola media. Ideologi ini memiliki kaitan dengan berbagai aspek di antaranya politik, ekonomi, budaya di negara media itu berada.

\section{HASIL DAN PEMBAHASAN}

Pemaparan Detik.com terhadap berita korban pengeroyokan oleh 'bobotoh' pada 23-28 September 2018, peneliti menggunakan metode analisis framing model Zhongdan Pan dan Gerald M. Kosicki dengan stuktur analisis: sintaksis, skrip, tematik, dan retoris. Analisis pembingkaian ini juga memungkinkan peneliti melihat makna apa di balik kata, kalimat, simbol, ide, serta unit analisis lainnya yang dapat membentuk makna tertentu pada suatu teks berita.

Peneliti mengambil media online Detik.com karena hanya media tersebut yang menyediakan timbal balik dengan pembaca berupa mood rating. Mood rating adalah bentuk timbal balik pembaca terhadap artikel berita yang tersedia pada setiap berita. Peneliti memilih Detik.com karena sepanjang periode 23-28 September 2018, jumlah pemberitaan pada media online tersebut, terkait pemberitaan meninggalnya HS seorang suporter 'the jak' di Bandung, yaitu Detik.com 72 berita. Peneliti mempersempit berita yang diteliti menjadi 1 (satu) berita/ hari atau selama periode 23 - 28 September 2018 total 6 (enam) berita berdasarkan persentase impresi terbanyak dari pembaca (Sandi, 2020).

Selain itu, peneliti menggunakan teori Hierarki Pengaruh (Shoemaker \& Reese, 1996: 313) untuk memperdalam penelitian tersebut. Peneliti juga melengkapi penelitian ini dengan melakukan wawancara sejumlah pihak dari media online Detik.com yang diwakili Kepala Biro Detik.com wilayah Jawa Barat \& Banten, serta wartawan yang terlibat dalam penulisan berita yang diteliti.

Dapat dilihat keenam berita yang menjadi objek penelitian memiliki kesinambungan satu sama lain. Ada upaya Detik.com untuk memberitakan kasus pengeroyokan ini mulai dari kejadian, penangkapan pelaku, penetapan tersangka, proses rekonstruksi, hingga vonis hukuman kedelapan pelaku pengeroyokan. Detik.com berupaya netral dalam memberitakan kasus pengeroyokan ini dengan tujuan menyudahi rivalitas suporter di Indonesia yang berujung hilangnya nyawa seseorang. Hal tersebut dibuktikan pada isi berita 3 dengan judul "Nyawa Suporter Persija Melayang, Setop Kekerasan di Sepakbola!".

Keenam berita memiliki pola pemberitaan yang hampir mirip yaitu dengan menyajikan berita sepotong-sepotong dengan maksud berupaya melakukan verifikasi lebih lanjut yang merupakan ciri khas Detik.com lalu diikuti oleh berbagai media online di Indonesia. Peneliti memahami karakteristik pembaca media online yaitu membaca di mana saja dan mudah dipahami secara cepat sehingga Detik.com menyadari hal itu dengan menyajikan berita sepotong-sepotong bahkan tak jarang sambungan berita tersebut muncul kembali hanya memodifikasi judul berita. Mengutip Margianto dan Syaefullah (2006), Detik.com selaku 
media online generasi pertama mengenalkan langgam berita baru: ringkas to the point, atas nama kecapatan berita Detik.com tidak selalu lengkap dengan unsur $5 \mathrm{~W}+1 \mathrm{H}$ layaknya pakem baku jurnalistik. Berdasarkan hasil penelitian keenam berita terlihat adanya perubahan pola Detik.com menyajikan berita dengan memperhatikan $5 \mathrm{~W}+1 \mathrm{H}$ secara lengkap.

Detik.com memanfaatkan identitas korban pengeroyokan untuk kepentingan bisnis media sebagai industri. Terlihat pemberitaan Detik.com terhadap kasus ini selama enam (6) hari berjumlah tujuh puluh dua (72) berita. Adapun tujuan Detik.com mengejar traffic ialah untuk menaikan pageview, sebab semakin besar pageview semakin besar potensi bisnis yang dapat diraih. Berhubungan dengan pageview, Detik.com mempraktikkan gaya penulisan berita yang update berita sepotong-sepotong atau berita yang di pecah-pecah. Mengutip Margianto dan Syaefullah (2006), ada asumsi bahwa berita sepotong-sepotong ialah ciri media online harus cepat dan merupakan perkembangan suatu peristiwa. Tapi, dalam perspektif bisnis, berita yang sepotong-sepotong ini menguntungkan karena dapat melipatgandakan pageview.

Detik.com tidak memperhatikan opini wartawan mereka yang kerap kali masuk ke dalam berita. Seperti pada berita "Peran 8 Tersangka Pengeroyokan Haringga Sirla Sampai Tewas" dan "Nyawa Suporter Persija Melayang, Setop Kekerasan di Sepakbola!" karena bertentangan dengan Pasal 3 Kode Etik Jurnalistik. Detik.com juga memperhatikan asas keberimbangan sesuai Pedoman Pemberitaan Media Siber pada berita "Polisi Amankan Sejumlah Bobotoh Terlibat Pengeroyokan di GBLA", "Peran 8 Tersangka Pengeroyokan Haringga Sirla Sampai Tewas", dan "Pengakuan Sadis Tersangka Pengeroyok Haringga Sirla".

\section{Pembahasan Struktur Sintaksis}

Diawali dengan struktur pertama yaitu penyusunan fakta atau sintaksis. Judul berita yang digunakan Detik.com pada kasus ini beberapa cukup menarik pembaca, sensasional dan sesuai dengan isi berita. Seperti judul "Nyawa Suporter Persija Melayang, Setop Kekerasan di Sepakbola!", "Pengakuan Sadis Tersangka Pengeroyok Haringga Sirla", dan "Suara Para Durjana Penganiaya Haringga Sirla". Namun, ada beberapa berita yang memiliki kesamaan isi berita dengan modifikasi judul agar terlihat berbeda seperti berita berjudul "Suara Para Durjana Penganiaya Haringga Sirla", "8 Tersangka Pengeroyokan Haringga Terancam 12 Tahun Penjara", dan "Pengakuan Sadis Tersangka Pengeroyok Haringga Sirla".

Keenam berita yang disajikan Detik.com merupakan keberlanjutan dari mulai kejadian pengeroyokan berujung tewasnya Haringga, penangkapan tersangka pengeroyokan, hingga hukuman yang menjerat tersangka. Meskipun terdapat berita yang isinya sama dengan modifikasi judul serta menambahkan sedikit informasi terbaru mengenai perkembangan kasus tersebut.

Selain itu, Detik.com memanfaatkan sumber yang terpercaya tidak mengambil informasi dari sumber berita yang lain. Terlihat keseriusan Detik.com untuk mengangkat kasus ini dengan menggunakan narasumber terpercaya seperti Kasatreskrim Polrestabes Bandung, Ketum PSSI Eddy Rahmayadi, hingga para pelaku sempat diwawancarai oleh Detik.com. Hal tersebut membuktikan bahwa dalam menyusun fakta, sumber yang didapat Detik.com dapat dipercaya kredibilitasnya. Namun, jika dilihat dengan asas keberimbangan berdasarkan Pedoman Pemberitaan Media Siber poin 2 (dua) butir (c) poin 2. Detik.com pada pemberitaannya memilih sumber berita yang kredibel dan kompeten. Seperti pada sumber berita "Polisi Amankan Sejumlah Bobotoh Terlibat Pengeroyokan di GBLA", "Peran 8 Tersangka Pengeroyokan Haringga Sirla Sampai Tewas", dan "Pengakuan Sadis Tersangka Pengeroyok Haringga Sirla".

Peneliti mewawancarai penulis berita "Polisi Amankan Sejumlah Bobotoh Terlibat Pengeroyokan di GBLA" untuk mengetahui tanggapan penulis mengenai asas keberimbangan 
154 | Kajian Jurnalisme

Volume 05 Nomor 02 Tahun 2022

DOI: $10.24198 / j \mathrm{kj} . v 5 \mathrm{i} 2.28886$

pada Pedoman Pemberitaan Media Siber.

Menurut peneliti sebaiknya wartawan menjunjung asas keberimbangan sehingga berita yang disajikan lebih menarik tidak dari satu sumber berita saja. Selain tidak berimbang, berita pun terlihat monoton karena hanya satu sumber saja yang dimunculkan.

Lead yang digunakan pada keenam berita tidak memiliki kesamaan. Setiap berita yang dimuat Detik.com memiliki variasi lead sehingga tidak memiliki kesamaan. Dengan begini, detik.com membuktikan medianya sebagai media daring tercepat tetapi dalam memberitakan informasi Detik.com memiliki kebaruan informasi tidak tambal-sulam. Namun, peneliti menemukan opini wartawan yang masuk ke dalam lead berita "Peran 8 Tersangka Pengeroyokan Haringga Sirla Sampai Tewas”. Penggunaan kata 'tanpa ampun' terlihat jelas opini wartawan masuk ke dalam berita tersebut. Peneliti mewawancarai penulis berita "Peran 8 Tersangka Pengeroyokan Haringga Sirla Sampai Tewas" untuk mengetahui tanggapan penulis mengenai opini dirinya yang masuk ke dalam lead berita.

\section{Pembahasan Struktur Skrip}

Struktur kedua yaitu cara wartawan mengisahkan fakta atau skrip. Dari keenam berita yang diteliti, Detik.com sangat menonjolkan unsur di mana. Rata-rata berita yang dimuat lokasinya yaitu stadion Gelora Bandung Lautan Api, Kota Bandung yang merupakan lokasi tempat kejadian perkara. Kemudian ada unsur apa, peristiwa yang paling menekankan ada pada berita "Polisi Amankan Sejumlah Bobotoh Terlibat Pengeroyokan di GBLA". Unsur apa ini terus berkembang hingga penetapan delapan tersangka dan hukuman yang menjerat para tersangka kasus pengeroyokan ini.

Unsur kapan ada pada wawancara dengan Kasatreskrim Polrestabes Kota Bandung AKBP Yoris Maulana dan Kapolrestabes Kota Bandung Irman Sugema pada hari kejadian 23 September 2018. Keenam berita menyantumkan sumber lengkap dengan waktu wawancara. Unsur bagaimana ditemukan pada akhirnya kedelapan tersangka divonis 12 tahun penjara.

Jika melihat hasil rangkuman peneliti di atas, struktur skrip yang digunakan detik.com sama saja tidak memiliki perubahan. Sebab struktur skrip $5 \mathrm{~W}+1 \mathrm{H}$ selalu lengkap pada keenam berita yang diteliti kali ini. Hasil penelitian pun menjelaskan bahwa Detik.com memiliki ciri yang menyajikan berita sepotong - sepotong atau berita bersambung untuk menarik khalayak pembacanya.

Penggunaan kutipan dan sumber pada keenam berita ini juga terdapat beberapa berita yang terlihat kurang berimbang karena hanya memfokuskan satu sudut pandang. Bahkan peneliti menemukan Detik.com pada beberapa berita hanya menggunakan satu sumber berita. Cepat dan update memang karakteristik media online seharusnya dipikirkan juga segi keberimbangan berita dengan ragam sudut padang agar media detik.com tidak di pandang salah satu media online yang tidak memikirkan asas keberimbangan. Hal tersebut tidak sesuai dengan Pasal 1 Kode Etik Jurnalistik.

\section{Pembahasan Struktur Tematik}

Struktur ketiga yaitu tematik, tema yang diangkat Detik.com merupakan kasus kejahatan dengan objek pengeroyokan suporter 'the jak' sampai meninggal oleh oknum 'bobotoh'. Tema berita kejahatan menarik karena memiliki news value dan news judgment tersendiri bagi para pembaca. Adapun yang termasuk news value ialah keluarbiasaan, kebaruan, akibat, aktual, kedekatan, informasi, konflik, tokoh atau ternama, human interest, kejutan, dan seks (Sumadiria, 2011: 80).

Tema ini menurut peneliti memiliki news value Human interest karena korban merupakan 
manusia yang layak hidup dan mati dengan wajar bukan dengan pengeroyokan. Keluarbiasaan karena peristiwa ini menambah daftar korban rivalitas antara 'jakmania' dan 'bobotoh' menjadi tujuh korban tewas karena rivalitas. Konflik pengeroyokan terjadi akibat konflik atau rivalitas yang tidak berujung serta hanya berujung dengan munculnya korban. Akibat dari pemberitaan ini muncul hal negatif serta positif, negatifnya memperpanjang rivalitas kedua suporter tersebut sedangkan positifnya adanya upaya damai antara kedua belah pihak suporter agar tidak muncul korban berikutnya.

Peneliti mewawancarai Kepala Biro Detik.com wilayah Jawa Barat \& Banten untuk mengetahui alasan Detik.com mengangkat tema kasus pengeroyokan suporter 'the jak' sampai meninggal oleh oknum 'bobotoh'. Berawal dari keprihatinan Detik.com atas terjadinya kasus ini hingga akhirnya mengangkatnya karena aktual dan human interest.

\section{Pembahasan Struktur Retoris}

Struktur terakhir yaitu cara wartawan menekankan fakta dengan kata, gambar, dan grafik atau retoris. Pemilihan kata yang menonjol dari enam berita yang diteliti adalah Haringga, pengeroyokan, dan tersangka. Detik.com menekankan HS seorang korban pengeroyokan oknum 'bobotoh'. Hal ini karena nama HS masuk trending topic karena sebelumnya beredar video pengeroyokan berujung tewasnya HS di media sosial.

Jika melihat foto ilustrasi yang digunakan pada keenam berita didominasi para tersangka dari mulai penetapan tersangka hingga proses rekonstruksi para tersangka. Dalam hal ini terlihat Detik.com cari langkah aman karena ada dua tersangka di bawah umur hal itu disamarkan dengan menggunakan topeng wajah agar identitas pelaku di bawah umur tidak diketahui. Hal tersebut sesuai dengan Kode Etik Jurnalistik Pasal 5.

Peneliti pun menemukan pemilihan kata yang tidak tepat dilakukan oleh penulis atau wartawan. Pada lead berita berjudul "Polisi Amankan Sejumlah Bobotoh Terlibat Pengeroyokan di GBLA" justru terjadi body shaming yang dilakukan penulis berita terhadap korban (HS). Body shaming sendiri tidak dibolehkan dalam kaidah jurnalistik karena melanggar UU ITE Pasal 27 ayat 3, dapat diancam hukum pidana 6 tahun.

Foto berita terdapat koreografi tersebut menggambarkan bahwa seorang 'the jak' sedang dikeroyok 'bobotoh' karena terdapat aksen darah yang keluar dari mulut pria berbaju orange. Menurut peneliti, pemilihan foto berita oleh wartawan cukup tepat karena menggambarkan rivalitas kedua suporter antara 'bobotoh' dan 'the jak'. Namun, foto tersebut dapat pula memanaskan suasana apabila 'the jak' dapat memaknai koreografi yang provokatif tersebut.

Peneliti menemukan penggunaan kata 'tewas' pada berita pertama. Kata 'tewas' memiliki makna secara tidak langsung bahwa 'the jak' merupakan korban perang. Jika melihat kasus ini merupakan rivalitas yang berujung munculnya korban. Seharusnya wartawan pada berita ini memperhatikan pilihan kata atau lexical choise menurut Pan \& Kosicki (1993) agar makna dari pemberitaan tidak bias ketika berupaya dimaknai oleh pembaca.

Pada berita "Polisi Amankan Sejumlah Bobotoh Terlibat Pengeroyokan di GBLA" hasil impresi pembaca terhadap berita tersebut $83 \%$ marah, 10\% sedih, $2 \%$ bangga, $2 \%$ terinspirasi, dan $2 \%$ terhibur. Peneliti sebagai pembaca pun menilai berita ini lebih kepada aksi pengeroyokan hingga berujung munculnya korban. Hal tersebut yang memicu kemarahan pembaca terhadap pemberitaan ini. Korban merupakan manusia yang layak hidup dan mati secara wajar bukan dengan aksi pengeroyokan seperti ini.

Pada berita "Peran 8 Tersangka Pengeroyokan Haringga Sirla Sampai Tewas" hasil impresi pembaca terhadap berita tersebut 92\% marah, 3\% takut, 3\% terinspirasi, dan 3\% senang. Peneliti sebagai pembaca pun menilai berita ini yang memunculkan motif tersangka. 
156 | Kajian Jurnalisme

Volume 05 Nomor 02 Tahun 2022

DOI: $10.24198 / \mathrm{jkj} . v 5 \mathrm{i} 2.28886$

Penggunaan balok dan besi untuk mengeroyok korban dirasa menjadi hal yang menyurut kemarahan pembaca terhadap tersangka pengeroyokan tersebut. Peneliti sebagai pembaca pun marah penggunaan kata 'tewas' pada judul dirasa kurang tepat sebab korban bukanlah hewan atau korban perang, korban merupakan manusia seharusnya penggunaan kata 'meninggal' lebih tepat untuk menggambarkan kondisi korban.

Pada berita "Nyawa Suporter Persija Melayang, Setop Kekerasan di Sepakbola!" hasil impresi pembaca terhadap pemberitaan ini ialah $100 \%$ marah. Aksi pengeroyokan ini sangat tidak layak terjadi lagi pembaca ingin rivalitas ini berujung perdamaian agar tidak ada korban yang meninggal karena kasus rivalitas. Peneliti sebagai pembaca pun menilai kasus Haringga ini sudah saatnya menjadi simbol perdamaian atau yang terakhir kali kasus rivalitas berujung hilangnya nyawa suporter.

Pada berita "Pengakuan Sadis Tersangka Pengeroyok Haringga Sirla" hasil impresi pembaca terhadap pemberitaan ini ialah $87 \%$ marah, $4 \%$ terinspirasi, $3 \%$ sedih, $2 \%$ terkejut, $2 \%$ bangga, $2 \%$ senang, dan $1 \%$ takut. Peneliti sebagai pembaca pun marah terhadap pengakuan motif tersangka yang tidak memiliki rasa kemanusiaan yang tinggi.

Pada berita "Suara Para Durjana Penganiaya Haringga Sirla" hasil impresi pembaca terhadap pemberitaan ini ialah $84 \%$ marah, $4 \%$ bangga, $4 \%$ terhibur, $3 \%$ terinspirasi, $3 \%$ sedih, dan $2 \%$ takut. Peneliti sebagai pembaca pun marah terhadap pengakuan motif tersangka yang tidak memiliki rasa kemanusiaan yang tinggi.

Pada berita "8 Tersangka Pengeroyokan Haringga Terancam 12 Tahun Penjara" hasil impresi pembaca terhadap pemberitaan ini ialah 75\% marah, $15 \%$ senang, $5 \%$ terinspirasi, dan $5 \%$ sedih. Peneliti sebagai pembaca pun merasa senang karena vonis 12 tahun penjara untuk para tersangka dirasa tepat. Peneliti menilai pembaca yang marah akibat kurang puas terhadap vonis tersebut seharusnya bisa dihukum seumur hidup karena setimpal dengan perlakuan pengeroyokan tersangka.

\section{Hierarki Pengaruh Terhadap Pemberitaan Korban Pengeroyokan oleh Oknum Bobotoh}

Peneliti juga menggunakan teori hierarki pengaruh yang dikemukakan Shoemaker dan Reese untuk mengetahui bagaimana berita dibentuk tidak hanya dipengaruhi oleh wartawan/ internal. Tapi, peran eksternal juga memiliki pengaruh. Shoemaker dan Reese membagi ke dalam beberapa level pengaruh isi media yang memengaruhi kebijakan redaksi dalam proses produksi berita, yaitu:

Level individu, yaitu berhubungan dengan latar profesional media. Dalam wawancara bersama Erna Mardiana via voice note, calon wartawan pertama tentu saja minimal harus S1, jurusan apapun. Kedua, punya integritas dan militansi yang tinggi. Ketiga, bisa menulis dan suka tantangan. Tidak ada kriteria pengalaman berapa lama. Fresh graduate yang minimal punya tiga kriteria di atas bisa jadi wartawan Detik.com. Tes tentu saja ada, psikotest dan wawancara serta tertulis. Jika seseorang lulus, maka menjadi calon reporter dengan evaluasi setiap 6 bulan selama 1 tahun. Setelah itu baru diangkat menjadi karyawan tetap (Mardiana, Wawancara. 18 April 2020).

Rutinitas Media, yaitu berhubungan dengan mekanisme dalam proses penentuan berita. Erna sebagai Kepala Biro Detik.com Regional Jawa Barat \& Banten mencari tahu terlebih dahulu kebutuhan masyarakat atas kasus ini. "Alur produksi media online tidak seribet media cetak. Wartawan yang di lapangan mengirimkan beritanya melalui email, lantas dikoreksi oleh editor di dalam kantor, terus upload. Setelah itu dilakukan pengembangan, apakah berita ini menarik untuk dikembangkan lebih lanjut atau tidak. Biasanya wapimred atau koordinator biro daerah memberikan arahan juga. Kita biasanya melakukan evaluasi data berita yang paling 
banyak dibaca hari itu. Kalau memang menarik dan banyak yang baca, keesokan harinya berita itu diperdalam kembali," (Mardiana, Wawancara. 18 April 2020). Selain mengetahui kebutuhan masyarakat dan memperdalam kasusnya, Erna juga melihat news value dan news judgment yang terkandung dalam peristiwa tersebut.

Level organisasi, yaitu berhubungan dengan organisasi media yang secara hipotesis memengaruhi pemberitaan. Dalam peristiwa ini Erna sebagai Kepala Biro mengatur wartawan Detik.com dalam penentuan angle. "Pimpinan seperti redpel kalo di Detik.com Kepala Biro turun tangan untuk penentuan angle. Serta selalu jaga integritas dengan investasi nama, lalu kroscek, kroscek.” (Indra, Wawancara. 18 April 2020).

Level ekstramedia, yaitu berhubungan dengan faktor eksternal media. Pengaruh tersebut berasal dari luar organisasi media, seperti sumber berita, pengiklan dan penonton, kontrol dari pemerintah, dan lain sebagainya. "Erna mengutamakan suara masyarakat yang ingin perdamaian antara 'bobotoh' dan 'the jak' terwujud. Dengan memberitakan setiap saat hingga vonis dijatuhkan pada 7 pelaku pengeroyok Haringga. Saya rasa Detik.com memilih netral terhadap peristiwa ini dengan memperhatikan suara yang tidak terdegar." (Mardiana, Wawancara. 18 April 2020).

Level ideologi, yaitu berhubungan dengan latar belakang profesional dari pengelola media. "Haringga Sirla bukan soal kekerasan suporter sepakbola, namun ini menjadi tragedi kemanusiaan. Itu alasan kami me-running berita ini terus-menerus dan mengikutinya hingga vonis dijatuhkan pada 7 pengeroyok Haringga Sirla. Dengan pemberitaan terus di media, di beberapa tempat seperti yang kami beritakan, muncul suara-suara keinginan perdamaian antara 'bobotoh' dan 'the jak'. Ini yang kami inginkan.” (Mardiana, Wawancara. 18 April 2020)

\section{SIMPULAN}

Dilihat dari struktur sintaksis, pembingkaian yang dilakukan Detik.com dapat dilihat dari penyusunan faktanya. Pada isi berita yang disajikan Detik.com menampilkan peristiwa yang sedang ramai di media sosial akibat viralnya video korban pengeroyokan oleh oknum 'bobotoh', yaitu sosok pria (HS) yang merupakan suporter Persija. Selain itu, Detik.com memanfaatkan nama korban (HS) sebagai judul di beberapa berita dengan tujuan menarik pembaca lebih banyak. Sesuai dengan keunggulan media daring yaitu kecepatan, kebaruan, serta praktis dalam kasus ini Detik.com mengangkat 72 berita selama satu pekan periode 23 - 28 September 2018. Dari keenam berita yang diteliti terdapat beberapa berita hanya menggunakan satu sumber. Hal tersebut sesuai dengan Pedoman Pemberitaan Media Siber karena sumber yang dipilih kredibel dan kompeten. Peneliti menemukan opini wartawan masuk ke dalam lead berita. Hal tersebut bertentangan denga Pasal 3 KEJ. Dilihat dari struktur skrip, cara Detik.com mengisahkan fakta sangat menonjolkan unsur di mana dari unsur $5 \mathrm{~W}+1 \mathrm{H}$. Dari keenam berita yang diteliti, unsur di mana dominan dibahas seperti lokasi peristiwa, lokasi olah tempat kejadian perkara, lokasi wawancara. Dilihat dari struktur tematik, tema yang diangkat Detik.com merupakan kasus kejahatan dengan objek pengeroyokan suporter 'the jak' sampai meninggal oleh oknum 'bobotoh'. Tema berita kejahatan menarik karena memiliki news value dan news judgment tersendiri bagi para pembaca.

Dilihat dari struktur retoris, cara Detik.com menekankan fakta dengan menggunakan kata, gambar, dan grafis untuk mendukung pembingkaiannya. Detik.com banyak memakai kata identitas korban (HS) untuk menarik pembaca dengan tujuan meraih keuntungan bisnis media. Peneliti juga menemukan kalimat wartawan melakukan body shaming terhadap korban (HS) hal itu bertentangan dengan UU ITE Pasal 27 ayat 3 Gambar yang digunakan Detik.com mendukung isi berita dan meyakinkan khalayak. Untuk segi foto, Detik.com memperhatikan 
158 | Kajian Jurnalisme

Volume 05 Nomor 02 Tahun 2022

DOI: $10.24198 / j \mathrm{kj} . v 5 \mathrm{i} 2.28886$

KEJ dengan memburamkan wajah pelaku yang dibawah 17 tahun. Dilihat dari hierarki pengaruh yang muncul dalam penelitian muncul level individu, Melakukan perekrutan reporter minimal sarjana apapun, memiliki integritas dan militansi yang tinggi. Jika dinyatakan lolos menjadi calon reporter, Detik.com akan melakukan evaluasi 6 bulan dalam 1 tahun. Rutinitas media, Detik.com melihat suatu kasus sesuai dengan kebutuhan pembaca dan memperhatikan nilai berita serta mengedepankan asas keberimbangan. Level organisasi, Reporter akan melakukan observasi, pencarian data dan narasumber. Selanjutnya, redaksi akan mengarahkan angle pemberitaan tersebut untuk mengantisipasi kesamaan berita dengan media lain. Level ekstramedia, Detik.com memperhatikan suara masyarakat yang ingin perdamaian 'bobotoh' dan 'the jak' terwujud. Oleh karena itu, Detik.com secara konsisten memberitakan kasus ini secara berimbang. Level ideologi, Detik.com memandang kasus ini merupakan kasus kemanusiaan. Oleh sebab itu, Detik.com me-running berita kasus ini secara konsisten dengan tujuan muncul suara-suara yang ingin perdamaian antara kedua suporter.

\section{DAFTAR PUSTAKA}

Adiprasetio, J. (2015). Hierarki pengaruh dalam mediasi pesan. Diakses 25 Mei 2021, dari Remotivi website: https://remotivi.or.id/kupas/245/hierarki-pengaruh-dalam-mediasipesan

Adiprasetio, J. (2019a). Copywriting dan jurnalisme: Tirto.id dan kiat memasarkan berita. In A. Suryana \& et al (Eds.), Eksistensi Promosi di Era Digital (pp. 45-56). Bandung: Bitread.

Adiprasetio, J. (2019b). Kekalahan jurnalisme di hadapan pasar dan pemasaran daring. In A. Suryana \& et al (Eds.), Eksistensi Promosi di Era Digital (pp. 9-21). Bandung: Bitread.

Adiprasetio, J. (2020). Under the shadow of the state: Media framing of attacks on West Papuan students on Indonesian online media. Pacific Journalism Review, 26(2), 240-258. https:// doi.org/10.24135/pjr.v26i2.1124

Adiprasetio, J., \& Larasati, A. W. (2020). Pandemic crisis in online media: Quantitative framing analysis on Detik.com's coverage of Covid-19. Jurnal Ilmu Sosial Dan Ilmu Politik, 24(2), 153-170. https://doi.org/10.22146/jsp.56457

Adiprasetio, J., \& Wibowo, K. A. (2019). A: Jurnalisme Banal dan Trivialisasi. In Media dan Pembangunan Berkelanjutan: Meneropong Peran Media Massa dalam Menunjang SDGs (pp. 1-22). Bandung: Bitread.

Cangara, H. (2003). Pengantar ilmu komunikasi. Jakarta: Raja Grafindo Persada.

D’Angelo, P., \& Kuypers, J. A. (2016). Doing news framing analysis: Empirical and theoretical perspectives. London: Routledge.

Detik.com. (2019). Sejarah singkat Detik.com.

Effendy, O. U. (2004). Ilmu komunikasi: teori dan praktik. Bandung: Remaja Rosdakarya.

Entman, R. M. (1993). Framing: Toward clarification of a fractured paradigm. Journal of Communication, 43(4), 51-58. https://doi.org/10.1111/j.1460-2466.1993.tb01304.x

Eriyanto. (2011). Analisis framing: Konstruksi ideologi dan politik media. Yogyakarta: LkIS.

Hapsari, I., \& Wibowo, I. (2015). Fanatisme dan agresivitas suporter klub sepak bola. Jurnal Psikologi, 8(1), 52-58. Diakses dari https://ejournal.gunadarma.ac.id/index.php/psiko/ article/view/1291

Margianto, J. H., \& Syaefullah, A. (2006). Media online: Pembaca, laba, dan etika: Problematika praktik jurnalisme online di Indonesia. Majalah Pusat Dokumentasi ELSAM, 33.

Margianto, J. H., \& Syaefullah, A. (2013). Media online: Pembaca, laba, dan etika. Jakarta: AJI Indonesia - Ford Foundation.

Mosco, V. (1996). The political economy of communcation. New York \& London: Sage. 
Nugroho, B. P. (2018). Total 7 suporter tewas akibat Persija vs Persib sejak 2012. Diakses dari detiknews website: https://news.detik.com/berita/d-4226127/total-7-suporter-tewasakibat-persija-vs-persib-sejak-2012

Pan, Z., \& Kosicki, G. (1993). Framing analysis: An approach to news discourse. Political Communication, 10(1), 55-75. https://doi.org/10.1080/10584609.1993.9962963

Ridwayanti. (2008). Hubungan identitas sosial dan konformitas kelompok.

Romli, A. S. M. (2014). Jurnalistik online: Panduan mengelola media online. Bandung: Nuansa Cendekia.

Sandi, M. R. (2020). Pemberitaan korban pengeroyokan oleh bobotoh (Analisis framing model Zhongdan Pan \& Gerald M. Kosciki pada media online Detik.com edisi 23-28 September 2018) (Universitas Padjadjaran). Universitas Padjadjaran. Diakses dari http://repository. unpad.ac.id/frontdoor/index/index/docId/34895

Santana, S. (2005). Jurnalisme kontemporer. Jakarta: Yayasan Obor.

Scheufele, D. A. (1999). Framing as a theory of media effect. Journal of Communication, 49(1), 103-122. https://doi.org/10.1111/j.1460-2466.1999.tb02784.x

Shoemaker, P. J., \& Reese, S. D. (1996). Mediating the message: Theories of influences on mass media content. London: Longman. https://doi.org/10.1177/1326365X14540245

Sobur, A. (2006). Analisis Teks Media Suatu Pengantar. Bandung: PT Remaja Rosdakarya.

Sukarmin, Y. (2010). Tindakan vandalisme suporter sepak bola: Penyebab dan penanggulangannya. Diakses darihttp://staffnew.uny.ac.id/upload/131411062/penelitian/ Tindakan+Vandalisme + Suporter + Sepak + Bola + Penyebab + dan + Penanggulangannya.pdf

Sumadiria, H. (2011). Jurnalistik Indonesia menulis berita dan feature: Panduan praktis jurnalis profesional. Bandung: Simbiosa Rekatama Media.

Suprobo, T., Siahainenia, R., \& Sari, D. K. (2016). Analisis framing media online dalam pemberitaan profil dan kebijakan menteri Susi Pudjiastuti (Studi pada situs berita Detik. com, Kompas.com dan Antaranews.com periode Oktober - Desember 2014). Cakrawala, 5(1), 119-138. Diakses dari https://ejournal.uksw.edu/cakrawala/article/view/499 